\title{
'Gut health': a new objective in medicine?
}

\author{
Stephan C Bischoff
}

\begin{abstract}
'Gut health' is a term increasingly used in the medical literature and by the food industry. It covers multiple positive aspects of the gastrointestinal (Gl) tract, such as the effective digestion and absorption of food, the absence of Gl illness, normal and stable intestinal microbiota, effective immune status and a state of well-being. From a scientific point of view, however, it is still extremely unclear exactly what gut health is, how it can be defined and how it can be measured. The Gl barrier adjacent to the GI microbiota appears to be the key to understanding the complex mechanisms that maintain gut health. Any impairment of the Gl barrier can increase the risk of developing infectious, inflammatory and functional Gl diseases, as well as extraintestinal diseases such as immune-mediated and metabolic disorders. Less clear, however, is whether Gl discomfort in general can also be related to $\mathrm{Gl}$ barrier functions. In any case, methods of assessing, improving and maintaining gut health-related $\mathrm{Gl}$ functions are of major interest in preventive medicine.
\end{abstract}

\section{Background}

In recent times, the term 'gut health' has become increasingly popular, as is evident by its more frequent use in the scientific literature and in the food industry [1]. In contrast to the medical understanding of the Western world, where gut issues are considered rather taboo, gut health is a central theme in Asian medicine, which recognises the abdomen as the location of the soul. "Honoured middle" (onaka) and "centre of the spiritual and physical strength" (hara) are how the Japanese describe our largest organ, the intestine, which for many Europeans is barely more than a simple digestive system which simply has to function [2]. On the other hand, gut health that is more than just a positive gut feeling is now also increasingly recognised in the

Correspondence: bischoff.stephan@uni-hohenheim.de

Institute of Nutritional Medicine, University of Hohenheim, Fruwirthstr. 12, Stuttgart, D 70599, Germany
Western world as a desirable aim and an important physiological condition required for overall good health. There may be two reasons for this. First, a growing number of people do not enjoy good gut health, as is indicated by the high prevalence of functional and organic gastrointestinal (GI) diseases in the Western world. Second, marketing professionals have discovered this concept for their own specific goals $[1,3]$. However, from a scientific point of view, it is still very unclear what gut health is, how it can be defined and how it can be measured. In the present article, current knowledge of gut health is summarised. Particular emphasis is given to the definition of the term, the underlying mechanisms, how to assess it and how to maintain it. Moreover, the possible impact of gut health for future, prevention-oriented medicine, as well as the need to increase understanding of this condition and to maintain it, is discussed.

\section{Discussion \\ Definition of gut health}

The expression 'gut health' lacks clear definition in the scientific literature, although it has been used repeatedly in human medicine [4-7] and in animal health [8,9]. According to the World Health Organisation (WHO) definition of 'health' from 1948, which proposes a positive definition instead of 'the absence of diseases', one might define gut health as a state of physical and mental well-being in the absence of GI complaints that require the consultation of a doctor, in the absence of indications of or risks for bowel disease and in the absence of confirmed bowel disease. Although the WHO defines health as being more than absence of disease, prevention or avoidance of disease is surely part of our understanding of health. Actually, gut health comprises a healthy upper and lower GI tract, although the term might suggest that it is restricted to the lower GI tract. However, other abdominal organs, such as the liver, pancreas, spleen or kidney, are usually not associated with gut health and therefore are not discussed here.

This definition covers the viewpoint of the potentially afflicted individual, who expects a largely symptom-free status that, at the very least, does not require consultation 
with a physician. It also covers the viewpoint of the doctor, who must bear in mind the potential risks of bowel diseases, particularly malignant bowel disease, even in the absence of any complaints by the patient. This definition, however, is based on exclusions and on more or less subjective criteria [10].

On the basis of the results of discussions within a scientific committee working on gut health issues, five major criteria have been defined that might form the basis for a positive and more objective definition of gut health (Table 1). The criteria could be confirmed in a questionnaire performed in a representative Western population group (SCB, unpublished work).

The relevance of gut health is underlined by the fact that the list of intestinal complaints that prompts an individual to consult a doctor is long, and such complaints are very common in the general population. They include symptoms associated with functional dyspepsia and irritable bowel syndrome (IBS) and comprise flatulence, bloating, regurgitation, heartburn, nausea, vomiting, constipation, diarrhoea, food intolerance, incontinence, abdominal pain and cramps, loss of appetite, weight loss and blood in stools. In most cases, such symptoms reflect more or less harmless diseases that might affect quality of life but not mortality. Some of the symptoms, however, such as anorexia, unintended weight loss, dysphagia, continuing vomiting, severe abdominal pain or diarrhoea, melena and hematochezia, have to be interpreted as alarm signals requiring a detailed examination. This is particularly important if such symptoms occur in individuals with a family history of colorectal carcinoma (CRC) or other malignant diseases or in individuals older than 50 years of age with a lack of colonoscopy. In these individuals, malignant GI diseases have to be excluded by appropriate means. Moreover, other chronic GI diseases, such as GI infections, GI immune diseases, inflammatory bowel disease (IBD), and antibiotic-associated diarrhoea, need to be excluded.

\section{Underlying mechanisms}

The GI tract contributes to health in many ways. Multiple data clearly indicate that the function of the gut is by far not restricted to food processing and subsequent nutrient and fluid uptake (Figure 1). Animal experiments and some human data have shown that the gut communicates with bacteria that support digestion by their enzymatic capacity $[11,12]$, that the gut regulates major epithelial and immune functions of importance for gut health and health in general $[13,14]$ and that the gut reports to the brain via the $\mathrm{N}$. vagus and hormones about energy uptake and other conditions that might affect mood and general well-being [15]. The details of how the gut has an impact on health in general have been reviewed in detail elsewhere [1,11-15] and are summarised in Figure 1. Of particular interest in this context is the recent finding in germ-free mice that the gut microbiota can directly influence not only GI functions but also the development of behaviour and corresponding neurochemical changes in the brain [16]. The mechanisms of how the gut microbiota contributes to gut health, however, are less clear.

There is now ample evidence that two functional entities are key to achieving and maintaining gut health [17-20]. These entities are the GI microbiome and the GI barrier, which is not just a mechanical barrier assessed by some permeability measurements. Instead, the current understanding of the GI barrier is more complex, since it refers to a functional entity consisting of epithelial defence and metabolic functions, the mucosal immune system and the enteric nervous system (ENS). The importance of this zone in the context of

Table 1 Gut health and gastrointestinal health ${ }^{a}$

\begin{tabular}{ll}
\hline Five major criteria for a healthy GI system & Specific signs of GI health \\
\hline Effective digestion and absorption of food & Normal nutritional status and effective absorption of food, water and minerals \\
& Regular bowel movement, normal transit time and no abdominal pain \\
Absence of Gl illness & Normal stool consistency and rare nausea, vomiting, diarrhoea, constipation and bloating \\
& No enzyme deficiencies or carbohydrate intolerances \\
& No IBD, coeliac disease or other inflammatory state \\
& No colorectal or other Gl cancer \\
Normal and stable intestinal microbiota & No bacterial overgrowth \\
& Normal composition and vitality of the gut microbiome \\
& No Gl infections or antibiotic-associated diarrhoea \\
& Effective Gl barrier function, normal mucus production and no enhanced bacterial translocation \\
Effective immune status & Normal levels of IgA, normal numbers and normal activity of immune cells \\
Immune tolerance and no allergy or mucosal hypersensitivity \\
Status of well-being & Normal quality of life \\
& 'Qi (ch'i)', or positive gut feeling \\
& Balanced serotonin production and normal function of the enteric nervous system
\end{tabular}

${ }^{\mathrm{a}} \mathrm{Gl}$, gastrointestinal; IBD, inflammatory bowel disease; IgA, immunoglobulin A. 


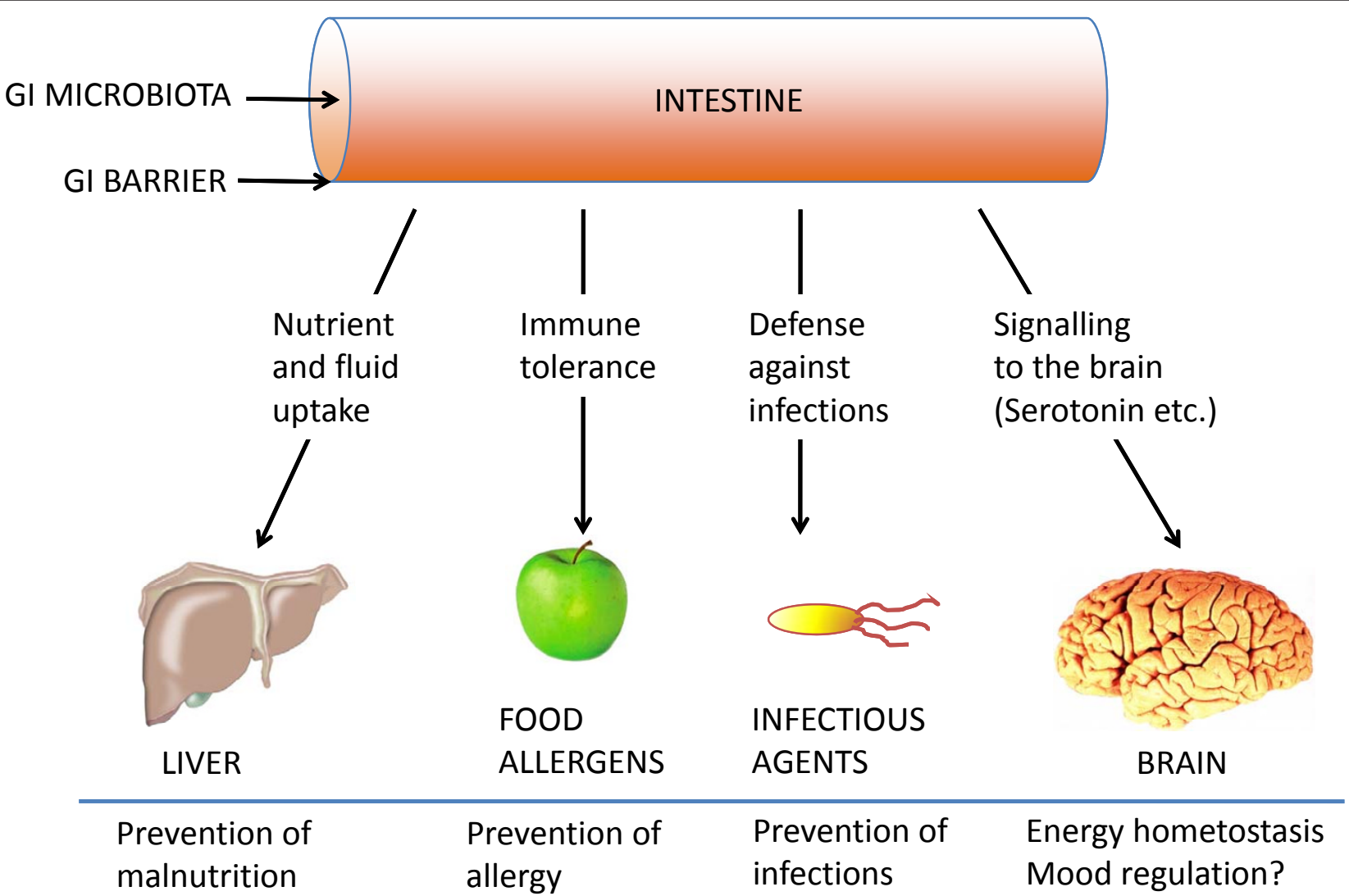

Figure 1 The intestine's impact on health. The gastrointestinal tract contributes to health by ensuring digestion and absorption of nutrients, minerals and fluids; by induction of mucosal and systemic tolerance; by defence of the host against infectious and other pathogens; and by signalling from the periphery to the brain. For details and references, see text 'Underlying mechanisms'.

this article is emphasised by the fact that it is the area of sampling and communication between host and luminal content. Therefore, not only permeability tests, which are known to have several serious limitations in themselves [21], but also the whole repertoire of tests recording GI functions need to be considered for the assessment of the GI barrier.

The GI microbiome consists of about $10^{14}$ bacteria that are mainly located in the large intestine $[22,23]$. Multiple functions of the GI microbiome have been described (see Figure 2). The GI microbiome prevents colonisation by potentially pathogenic microorganisms, provides energy for the gut wall from undigested food (for example, carbohydrates and other nutrients) and it regulates the mucosal immune system, not only educating the naive infant immune system but also serving as an important source of immune stimulators throughout life [24-29]. Thus, the GI microbiota contributes to energy homeostasis, prevents mucosal infections and likely mitigates immune system hypersensitivity. Most important, it contributes to the maintenance of an intact GI barrier, which seems to be closely related to infectious, inflammatory and allergic diseases [20,30].
Any impairment of the GI microbiome, for example, by administration of oral antibiotics [31-33] or by an unbalanced diet such as a carbohydrate-rich diet [34,35], and SCB, (unpublished work), will affect the functionality of the host's local defence systems. On the other hand, any malfunction of the epithelium, the immune cells or the ENS will affect microbiota diversity and functionality. In particular, the GI barrier, and consequently gut health, will be directly altered not only by local disturbances (such as increased epithelial permeability due to infection or any loss of function of particular immune cells and their mediators) but also by any systemic burden such as reduced oxygenation in intensive care unit patients, malnutrition in cancer patients and the elderly or altered nerve input because of ongoing stress or depression [36-42]. Thus a normal GI microbiota of rich diversity, as well as an intact GI barrier that counteracts the bacteria and cooperates with the commensal flora, is needed to maintain gut health.

The clinical consequences of such interrelationships are only just beginning to be understood. For example, antibiotic effects on gut microbiota composition and functionality can now be assessed by novel GI microbiota 


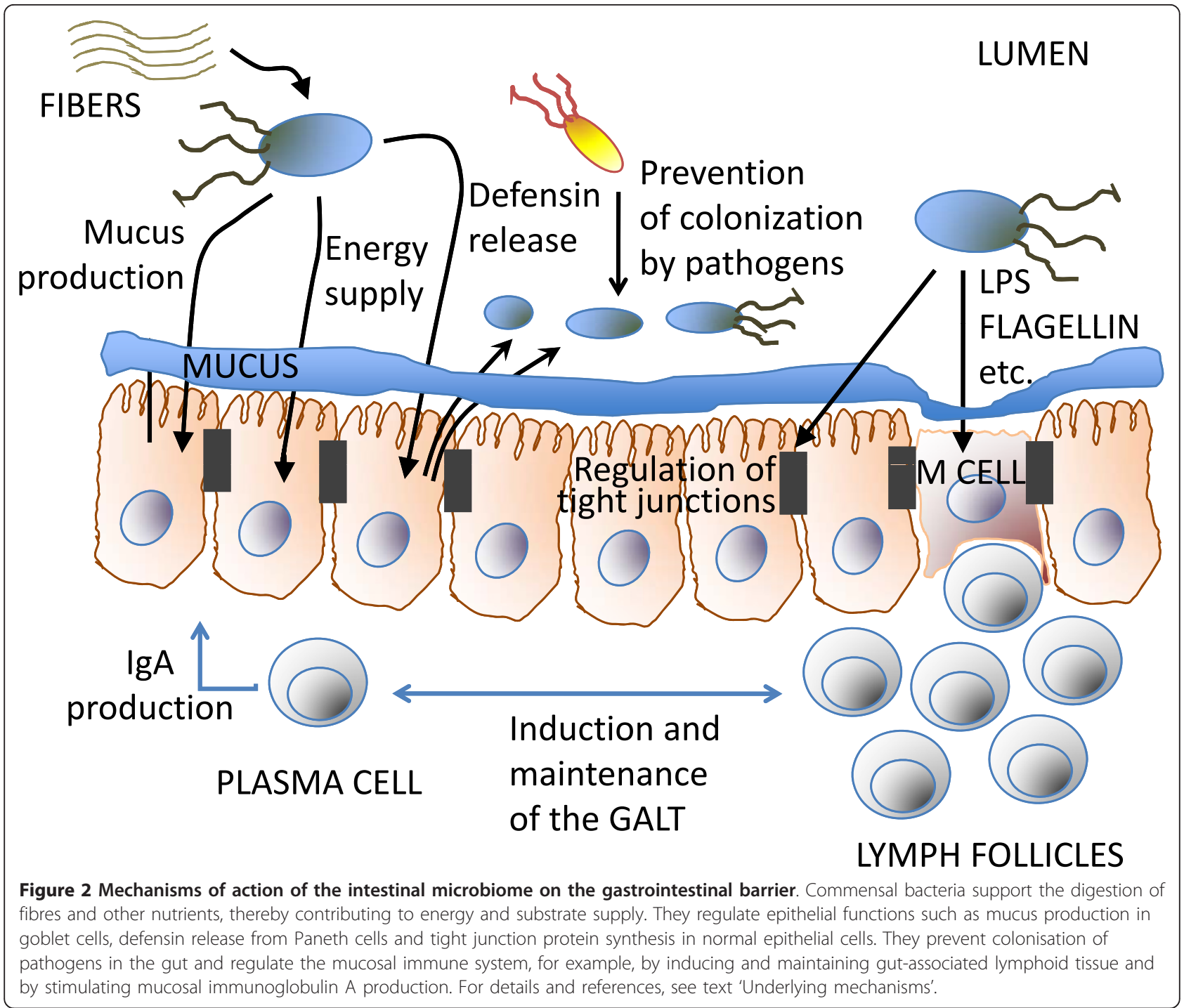

analytical technologies. Such innovative methods have been used to show that antibiotics such as ciprofloxacin influence the abundance of about one-third of the bacterial taxa in the gut, decreasing the taxonomic richness, diversity and distribution of the flora. In all the individuals tested in one study [33], the taxonomic composition of the flora closely resembled its pretreatment state four weeks after antibiotic treatment had finished, but there were several taxa that failed to recover within six months. These data conflict with prior assumptions that ciprofloxacin has only a modest effect on the intestinal microbiota. This example illustrates how quickly and unintentionally the GI microbiota can be changed, and we are just starting to realise the possible long-term consequences of such manipulations. Further establishment of diagnostic means to assess quickly and accurately the GI microbiome composition using molecular techniques will in the future allow us not only to describe in more detail the multiple relationships between the colonic microbiota and poor gut health but also to assess the impact of interventions intended to restore a healthy microbiota in the gut, such as dietary changes and the administration of probiotics, prebiotics or antibiotics $[30,43,44]$.

The mucosal immune system of the GI tract both controls the GI microbiome and depends on it. The permanent challenge of bacterial antigens to the mucosal immune system is required for its normal development and function $[24,25]$. In this context, it is not surprising that the GI immune system contains cells capable of recognising bacterial antigens by specific receptors, such as T-cell receptors (TCRs) and B cell-derived, surfacebound antibodies of the adaptive immune system, as well as Toll-like receptors (TLRs) and other pattern recognition receptors (PRRs) of the innate immune system. Dendritic cells (via TLRs), lymphocytes (via TCRs 
and antibodies) and innate immune cells such as macrophages and mast cells (via TLRs and other PRRs) are also involved in communication between the GI microbiome and the GI immune system so that any danger from pathogens can be recognised and also to maintain the friendly coexistence of bacteria and host in the gut [45-48].

To achieve the defence of the host against luminal bacteria and other potentially harmful substances, the GI immune system is equipped with specific tools, such as the plasma cell-dependent immunoglobulin A (IgA) defence system, goblet cell-derived mucus production and the synthesis of antimicrobial peptides such as defensins by Paneth cells [20,49-51]. All of these tools play a part in controlling the GI microbiome and protecting the host against invasion of luminal bacteria through the gut wall. Under normal conditions, these mechanisms also prevent direct contact between commensal bacteria and the GI epithelium [52]. Moreover, the GI immune system allows regulation of inflammatory responses to harmless antigens, such as food antigens or bacterial antigens derived from commensals, by mechanisms that together result in mucosal tolerance. The details of these mechanisms are not fully understood, but it is clear from numerous observations that loss of bacterial challenge and loss of immune tolerance results in severe hypersensitivity reactions, leading to chronic inflammatory states such as allergic disease, autoimmune disease and IBD [53,54]. Thus the GI immune system contributes to both the defence against and the acceptance of bacteria, and it fends off bacteria yet also needs them, all of which illustrate the complex balance of interactions between the GI microbiome and the GI immune system that protect the host and maintain gut health.

In addition to the mucosal immune system, the ENS is another perplexing and complex control and defence system that is starting to become understood. The ENS contains $10^{8}$ neurons and forms the largest neuronal network outside the brain. It monitors luminal conditions via sensory receptors and primary afferent neurons activated by secretagogues from enterochromaffin cells or mast cells such as biogenic amines (serotonin and histamine) or proteases $[55,56]$. The ENS is strikingly independent from the central nervous system (CNS), yet it regulates almost all major functions of the gut, such as epithelial secretion, absorption and permeability; immune functions; and, as shown most recently, even the GI microbiota [40,41]. GI infections, oral administration of antibiotics and chronic diseases such as IBS are clearly associated with morphological and functional changes in the ENS, which emphasises its role in mucosal defence. The ENS mediates multiple as yet undefined signals to the brain that seem to touch our awareness only under pathological conditions. Recent experimental studies strongly suggest that luminal conditions and signals, as well as the intestinal microbiota, are integrated into a gut-brain axis (GBA). For example, the stressinduced adrenocorticotropin hormone response in animals is much more pronounced in germ-free mice than in colonised animals [57]. Such interrelationships might provide a scientific basis for any 'gut feeling' or the above-mentioned Asian understanding of the gut being the centre of spiritual and physical strength. The first hints that CNS diseases such as hepatic encephalopathy, depression and autism spectrum disorder might be treated by modulating the GI microbiome (for example, with the prebiotic and laxative lactulose, sugar-reduced diets or antibiotics) is a further argument for the relevance of the GBA [58-60]. Moreover, experimental data have shown that probiotics, by modifying the GI microbiome, can affect both the ENS [61] and the CNS [62], which highlights the relevance of the CNS for gut health. Such findings might explain, at least in part, why probiotics can show effects outside the GI tract.

The question of genetic factors that might influence gut health is difficult to answer, because valid data are lacking. Although a few IBS studies on familial associations and gene polymorphisms have suggested that genetic factors might play a role in the pathogenesis of this disease $[63,64]$, the converse argument that genetic factors determine gut health is not justified yet. In particular, polymorphisms have been examined only in rather small groups, and familial associations do not exclude that environmental factors, including biological, psychological and sociological components, also play a role. Moreover, apart from human gene polymorphisms, bacterial genetic variations have to be considered in this context [65]. Genetic and environmental factors affecting gut health are not mutually exclusive, since most chronic diseases, including somatic syndromes and IBS, are likely related to both $[63,66]$. In this context, it is interesting to note that IBS is now also recognised from an epigenetic perspective on the basis of animal studies and a few human data (reviewed in [67]). This emerging field could in the future improve our understanding of how diet and the gut microbiota might influence gut health. Most excitingly, recent data in germ-free and colonised mice indicate that commensal microbiota profoundly shape the invariant natural killer T-cell compartment, a major component of the host immune system, through an epigenetic mechanism [68]. Other groups have shown that selected bacterial strains can induce regulatory cells that protect against pathogentriggered or allergen-induced inflammation [69]. Such data strongly suggest that both genetic and epigenetic factors are involved in the maintenance of gut health. 
In summary, the key to understanding gut health is an awareness that the GI barrier consists of multiple epithelial functions, the mucosal immune system, the ENS as well as the tissue matrix, the muscle layers and the blood supply. The GI barrier not only protects the host against potential dangers from the GI lumen but also allows food and liquid uptake, beneficial cross-talk to commensal bacteria and immune tolerance against harmless antigens. An intact GI barrier maintains gut health, whereas disturbance of GI barrier functions is increasingly recognised as an early but essential step in the pathogenesis of many GI diseases and even extraintestinal diseases.

\section{The GI microbiota and the GI barrier: implications for disease}

There is an ever-growing list of diseases for which alterations of the GI barrier have emerged as a crucial event in disease pathogenesis, and this list includes relevant GI and extraintestinal diseases (Table 2). It is striking that many of these diseases are characterised by an altered GI microbiota, further suggesting a link between GI barrier function and GI microbiota composition. The references cited in Table 2 demonstrate several examples of an association between changes in microbiota and disease, although the mechanisms of interaction are not always evident. On the other hand, because of such associations, it is tempting to speculate that the maintenance of normal microbiota and a stable GI barrier contributes to gut health and likely to health in general.

\section{How to test gut health?}

Gut health is frequently talked and written about but rarely if ever measured, because the boundaries and characteristics of this kind of 'wellness' are ill-defined. Diagnostic efforts are mostly oriented towards measurement of pathological situations, but the progress and importance of preventive medicine makes assessment of normal organ functions an increasingly relevant exercise.
To assess gut health, diagnostic methods must cover both subjective complaints and objective parameters.

Complaints cannot be assessed without registering an individual's history by using a questionnaire or performing a structured personal dialogue, for example, with the doctor. Questionnaires, ideally combined with some biomarkers of prognostic relevance, are also appropriate to screen a population and to accustom people to this particular issue, which is still often considered taboo. Such an approach requires validated tools adapted to bowelrelated complaints and symptoms that would enable clinicians to record improvements in well-being, quality of life and prognosis in selected populations (Table 3 ).

One such questionnaire is the Inflammatory Bowel Disease Questionnaire (IBDQ), a validated and reliable tool used to measure health-related quality of life (HRQoL) in adult patients with IBD, ulcerative colitis and Crohn's disease [70]. Whether the IBDQ can also be used to assess HRQoL in the general population still needs to be tested. One advantage of this questionnaire is that it has been adapted and validated in several languages and cultural milieus. A more general tool is the Bowel Disease Questionnaire (BDQ), which aims to distinguish patients with functional GI disease from those with other conditions such as IBD or CRC [71]. Logistic regression and discriminant analyses have shown that the BDQ is a valid measure of symptoms of functional GI disease. Probably the most suitable HRQoL assessment tool is the Irritable Bowel Syndrome-Quality of Life questionnaire, because IBS is the disease entity closest to the borderline between gut health and GI disease [72]. The Health Status Questionnaire-12 (HSQ-12) is another reliable, valid, low-cost measure of health status that was created to assess the general population [73]. The HSQ-12, in contrast to the also validated 12-item Short Form Health Survey (SF-12), can distinguish between people with and without dementia [74]. On the other hand, both the HSQ-12 and the SF-12 assess general health status, but not specifically gut health. Therefore, a short general questionnaire could be combined

Table 2 Diseases thought to be associated with GI barrier and GI microbiota ${ }^{a}$

\begin{tabular}{lll}
\hline Location & $\begin{array}{l}\text { Diseases for which the GI barrier plays a central role in } \\
\text { pathogenesis }\end{array}$ & $\begin{array}{l}\text { Diseases associated with an altered composition or function of } \\
\text { the Gl microbiota }\end{array}$ \\
\hline Intestinal & Infectious diarrhoea [26,36] & Inflammatory bowel disease [138,139] \\
& Inflammatory bowel disease [130-132] & Coeliac disease [140] \\
& Coeliac disease [131] & \\
& Irritable bowel syndrome [133] syndrome [141,142] \\
Extraintestinal & Allergic diseases [20,134,135] & Allergic diseases [143,144] \\
& Autoimmune diseases and arthritis [17] & Arthritis [145] \\
& Obesity, fatty liver disease and nonalcoholic steatohepatitis & Obesity [125] \\
& (NASH) [35,136,137] & \\
& Systemic inflammatory response syndrome (SIRS) and sepsis in & \\
ICU patients [36,37] & \\
Malnutrition [40]
\end{tabular}

${ }^{\mathrm{a}} \mathrm{Gl}$, gastrointestinal; ICU, intensive care unit. 
Table 3 Assessment of normal gut function ${ }^{a}$

\begin{tabular}{|c|c|c|}
\hline \multicolumn{2}{|l|}{ Assessments and parameters } & \multirow[t]{2}{*}{ Descriptions } \\
\hline \multicolumn{2}{|l|}{ Subjective assessments of well-being } & \\
\hline \multirow{5}{*}{$\begin{array}{l}\text { Validated questionnaires useful to } \\
\text { assess quality of life and gut health }\end{array}$} & IBS-Quality of Life (IBS-QOL) & Validated for assessment of quality of life specific to IBS: 34 questions \\
\hline & $\begin{array}{l}\text { Inflammatory Bowel Disease } \\
\text { Questionnaire (IBDQ) }\end{array}$ & $\begin{array}{l}\text { Validated for assessment of health-related quality of life (HRQOL) in adult } \\
\text { patients with IBD }\end{array}$ \\
\hline & $\begin{array}{l}\text { Bowel Disease Questionnaire } \\
\text { (BDQ) }\end{array}$ & Validated to distinguish patients with functional and organic Gl disease \\
\hline & $\begin{array}{l}\text { Health Status Questionnaire (HSQ- } \\
12)\end{array}$ & Validated for assessment of HRQOL in the general population \\
\hline & $\begin{array}{l}\text { Short Form Health Survey SF-12 } \\
\text { (SF-12) }\end{array}$ & Validated for assessment of HRQoL in the general population \\
\hline \multirow[t]{10}{*}{ Gl symptom scores } & $\begin{array}{l}\text { IBS Severity Scoring System (IBS- } \\
\text { SSS) }\end{array}$ & $\begin{array}{l}\text { Validated for scoring lower } \mathrm{Gl} \text { symptoms on the basis of nine questions; } \\
\text { range of } 0 \text { to } 500 \text { points }\end{array}$ \\
\hline & $\begin{array}{l}\text { Short Form Leeds Dyspepsia } \\
\text { Questionnaire (SF-LDQ) }\end{array}$ & Validated instrument for measuring the presence and severity of dyspepsia \\
\hline & $\begin{array}{l}\text { Gastrointestinal Symptom (GIS) } \\
\text { profile }\end{array}$ & $\begin{array}{l}\text { Validated for assessment of symptoms of functional dyspepsia; } 10 \\
\text { questions }\end{array}$ \\
\hline & $\begin{array}{l}\text { Subject's Global Assessment of } \\
\text { Relief (SGA) }\end{array}$ & $\begin{array}{l}\text { Validated assessment of the impact of treatment on IBS-related symptoms; } \\
1 \text { question }\end{array}$ \\
\hline & $\begin{array}{l}\text { IBS Global Assessment of } \\
\text { Improvement (IBS-GAI) ("adequate } \\
\text { relief") }\end{array}$ & $\begin{array}{l}\text { Asks participants if, compared to the way they felt before entering the } \\
\text { study, their IBS symptoms have changed over the past } 7 \text { days; } 1 \text { question }\end{array}$ \\
\hline & $\begin{array}{l}\text { Functional Bowel Disorder } \\
\text { Severity Index (FBDSI) }\end{array}$ & $\begin{array}{l}\text { Validated score for assessment of patient perception of abdominal pain in } \\
\text { IBS }\end{array}$ \\
\hline & $\begin{array}{l}\text { Numeric Rating Scale (NRS) for } \\
\text { assessment of pain }\end{array}$ & Validated in IBS patients \\
\hline & Visceral Sensitivity Index (VSI) & $\begin{array}{l}\text { Validated psychometric instrument that measures Gl symptom-specific } \\
\text { anxiety }\end{array}$ \\
\hline & $\begin{array}{l}\text { Bristol Stool Scale/Bristol Stool } \\
\text { Chart }\end{array}$ & $\begin{array}{l}\text { A medical aid designed to classify the form of human faeces into seven } \\
\text { categories }\end{array}$ \\
\hline & $\begin{array}{l}\text { Gastrointestinal Symptom Rating } \\
\text { Scale }\end{array}$ & \\
\hline Eating habits & Food frequency questionnaire & 7-day diet history assessed using computer software \\
\hline \multicolumn{3}{|l|}{ Objective parameters } \\
\hline \multirow[t]{5}{*}{ Markers of functionality } & Gastric function & $\begin{array}{l}\mathrm{pH} \text { metry in the esophagus [6,7] and stomach [1-3], gastroesophageal } \\
\text { reflux episodes ( }<50 / \text { day, }<60 \text { minutes total), viscosity of the luminal } \\
\text { content using a viscometer, stool weight }(>100 \mathrm{~g} / \mathrm{d},<500 \mathrm{~g} / \mathrm{d}) \text { and stool } \\
\text { consistency (water content) }\end{array}$ \\
\hline & Permeability measurements & Tracer molecules (lactulose/mannitol, ${ }^{51} \mathrm{Cr}$-EDTA, PEG); \\
\hline & Motility tests & $\begin{array}{l}\text { Barostat, gastric scintigraphy, }{ }^{13} \mathrm{C} \text { urea breath test (gastric emptying) and } \\
\text { lactulose hydrogen breath test (normal range: } 40 \text { to } 240 \text { hours) }\end{array}$ \\
\hline & Transit time & $\begin{array}{l}\text { Radiopaque pellets (Hinton test) and isotope-labelled test meal (normal } \\
\text { range: } 24 \text { to } 168 \text { hours) }\end{array}$ \\
\hline & Digestion parameters & $\begin{array}{l}\text { Stool elastase }(>200 / \mathrm{g}) \text { and stool fat }(<7 \mathrm{~g} / \mathrm{d}) \text {, carbohydrate breath tests, } \\
\text { anthropometry and micronutrient analysis }\end{array}$ \\
\hline \multirow[t]{3}{*}{ Markers of intestinal integrity } & Epithelial integrity & $\begin{array}{l}\text { Histology (villus height/crypt depth ratio, mitosis and apoptosis), mucus } \\
\text { secretion (mucins and trefoil peptides) and Ussing chamber (ion fluxes and } \\
\text { electric potentials) }\end{array}$ \\
\hline & Specific molecules & $\begin{array}{l}\text { E-cadherin, growth factors, tight junction molecules, } \alpha_{1} \text {-antitrypsin in faeces } \\
\text { and LPS in blood }\end{array}$ \\
\hline & Antimicrobial peptides & $\begin{array}{l}\alpha \text { - and } \beta \text {-defensins, calprotectin, lysozyme or neutrophil-derived elastase in } \\
\text { faeces }\end{array}$ \\
\hline \multirow[t]{2}{*}{ Marker of intact immunity } & Cell counts and phenotyping & $\begin{array}{l}\text { Differential blood count and FACS analysis, histopathology of intestinal } \\
\text { biopsies and immunohistochemistry of intestinal biopsies }\end{array}$ \\
\hline & Cell mediators and cytokines & $\begin{array}{l}\text { Inflammatory cytokines (IL-1, IL-6 and TNF } \alpha \text { ), anti-inflammatory cytokines } \\
\text { (IL-10 and TGF } \beta \text { ), regulatory cytokines (IL-2, sIL-2R, IL-4, IL-5 and so on), } \\
\text { proteases (tryptase, chymases, chymotrypsin and so on), immunoglobulins } \\
\text { (IgA, slgA and IgE) and others (retinoic acid, neuropeptides and so on) }\end{array}$ \\
\hline
\end{tabular}


Table 3 Assessment of normal gut function ${ }^{a}$ (Continued)

\begin{tabular}{|c|c|c|}
\hline & Functional assays & $\begin{array}{l}\text { Cell cultures and cocultures, DTH response, phagocytosis, chemotaxis, } \\
\text { oxidative burst (superoxide anion generation) and NK cell activity }\end{array}$ \\
\hline \multirow{2}{*}{$\begin{array}{l}\text { Analysis of the intestinal } \\
\text { microbiome }\end{array}$} & Classical approaches & Bacterial culture and toxin measurements \\
\hline & New approaches & $\begin{array}{l}\text { Metagenomics (PCR and full bacterial sequencing), metabonomics } \\
\text { (metabolic capacity of the microbiome) }\end{array}$ \\
\hline
\end{tabular}

with a gut-related one, although this combination has yet to be evaluated.

It may be helpful to combine such questionnaires with, for example, the Gastrointestinal Symptom Rating Scale, consisting of 15 questions on symptoms [75], or the Bristol Stool Scale, which classifies the form of human faeces into seven categories, with types 1 and 2 indicating constipation, types 3 and 4 being the ideal stools', and types 5 to 7 suggesting diarrhoea or bowel urgency [76]. Other disease-related GI symptom scales that have been validated are the IBS Severity Scoring System for scoring lower GI tract symptoms and the Leeds Dyspepsia Questionnaire or the Gastrointestinal Symptom profile for scoring upper GI tract symptoms [77-79]. Moreover, scores have been developed and tested which assess particular symptoms, such as pain, using the Functional Bowel Disorder Severity Index or the Numeric Rating Scale $[80,81]$, as well as scores that assess anxiety using the Visceral Sensitivity Index [82]. In clinical trials, overall improvement of symptoms has been assessed by using singular global questions such as the IBS Global Assessment of Improvement or the Subject's Global Assessment of Relief, which have yielded reliable results $[83,84]$.

Bowel functions are extremely complex and variable; therefore, objective assessment is a difficult task. Nevertheless, multiple approaches have been used to assess a range of bowel functions. For example, glucose challenge with a subsequent hydrogen breath test was believed to identify individuals with so-called 'abnormal bacterial colonisation' of the intestine as a possible cause of deterioration of gut health. Over the past few years, there have been impressive developments in techniques for analysing the human microbiome, such as using metagenomic-metabonomic linkage analyses or small subunit ribosomal RNA hypervariable tag sequencing $[7,30,43,44,85]$. Microbiome analysis, however, is still considered inappropriate for routine diagnosis of gut function or gut health. However, even modern molecular techniques do not yet allow the definition of what can be considered a 'normal' or 'optimal' microbiome composition. On the other hand, an increasing number of immunological parameters have become available, among which cell counts and cell phenotyping by flow cytometry and immunohistology and quantification of cytokines, antibodies and mediators are the most well-known tools (Table 3).

Despite an increasing number of more or less validated laboratory methods for objective assessment of bowel function, the perception of the individual should never be ignored. Only direct conversation between a doctor and patient allows the opportunity of being able to register GI-specific sensations that are pleasant, which are primarily related to the intake of meals and the evacuation of faeces, that is, gratifying sensations, such as satiation and complete rectal evacuation. Other physiological events, such as eructation and the emission of wind from the anus, may also contribute to GI wellbeing. Sensations related to thirst, taste, smell and the desire of specific types of foods (salts or sweets, for example) should also be considered part of this concept. Patients with so-called functional GI diseases lose such pleasant sensations, the perception of which will be modulated by age, sex, cultural background and psychological stress.

\section{How to maintain gut health?}

Our knowledge about how to maintain or restore gut health is limited in evidence-based medicine terms, but general observations suggest that there is a wide range of possible ways to support gut health and GI wellbeing. Current medical research is much more focused on the treatment of defined GI disease rather than on the secondary or even primary prevention of disease. For example, we know of several effective drugs to treat acute IBD and a few to support remission, but almost nothing to prevent IBD, a situation that might be related not only to pathophysiological circumstances. On the other hand, preventive medicine is increasingly perceived as being important in medical and economic terms, particularly in the field of gastroenterology, where we have to deal with a broad grey area between suboptimal health and disease.

Many approaches to maintaining gut health and preventing GI diseases such as infection, antibioticassociated diarrhoea, IBD, IBS, food allergy and so on 
are related to the hygiene hypothesis. This concept maintains that any disturbance of the balance between the microbiome and the mucosal immune system will lead to impairment of the GI barrier and subsequently to an increased risk to gut health and subsequent development of GI disease [53,86-88]. Therefore, any conditions that might disturb the intestinal microbiome and the mucosal immune system should be avoided, such as not only unbalanced diet and lack of exercise but also extreme exercise and any type of chronic stress. In recent publications, high-fat as well as high-fructose diets have been shown to disturb the GI barrier and, in this way, to induce fatty liver disease and subclinical inflammatory conditions associated with metabolic disturbances $[35,89,90]$. On the other hand, dietary changes have been shown to help prevent major diseases such as allergy, obesity and cancer [20,90,91]. Therefore, a balanced diet that includes high vegetable and fibre content and moderate consumption of red meat to prevent colon cancer $[92,93]$, or an individualized elimination diet in selected individuals with food intolerances, food allergy or coeliac disease $[94,95]$, might contribute to gut health. Moreover, tobacco abstinence, moderate alcohol consumption, maintenance of normal body weight, avoidance of nonsteroidal anti-inflammatory drug (NSAID) ingestion and control of stress can support gut health. Systematic strategies to improve lifestyle and to avoid or reduce stress that have been validated in controlled trials are rare; however, meditative methods that often originate from traditional Chinese medicine and other Asiatic cultures (for example, ayurveda and tai-chi) are enjoying growing popularity and becoming increasingly accepted by health professionals as valuable tools to maintain gut health and general well-being [96,97].

Chemoprevention by taking aspirin, cyclooxygenase 2 inhibitors and calcium may reduce the recurrence of adenomas and/or the incidence of advanced adenomas in individuals with an increased risk of $\mathrm{CRC}$, and taking aspirin may reduce the incidence of $C R C$ in the general population [98]. However, both aspirin and NSAIDs are associated with adverse effects, so it will be important to consider the risk-benefit ratio before recommending these agents for chemoprevention. Other chemopreventive strategies, such as retinoid-based therapy and tumour necrosis factor-related, apoptosis-inducing ligand in patients at risk for CRC, are based on animal experiments and need to be confirmed in human studies [99]. In the upper GI tract, chemopreventive strategies, such as the use of celcoxib, have been shown to be less successful [100]; therefore, endoscopic surveillance strategies are still indispensable in patients at risk for GI malignancies.
An interesting idea is whether gut health can be further supported by using modulators of the intestinal microbiome or the GI barrier, such as probiotics or prebiotics. Indeed, it has been shown that chronic bowel diseases such as IBD are associated with adherence of commensal bacteria to the otherwise sterile intestinal epithelium [101] and that selected probiotics can prevent the adhesion of pathogenic bacteria to the intestinal mucosa [102] or restore leaky gut by improving the molecular composition of tight junctions [103,104]. Moreover, probiotic bacteria can support the normal development of the mucosal immune system, such as through the $\mathrm{C}-\mathrm{C}$ chemokine receptor 6 (CCR6) gene expressed on lamina propria lymphocytes [24] and the production of protective IgA and antimicrobial defensins such as the CCR6 ligand human $\beta$-defensin 2 (or hBD2) $[105,106]$ that are both lacking in many chronic IBDs [51]. These few selected examples indicate the strong rationale for using probiotics, possibly also in synergistic combinations with prebiotics, to maintain gut health.

We have good data now, even meta-analyses including more than 1,000 individuals, on probiotic effects in preventing or attenuating acute gastroenteritis, antibioticassociated diarrhoea, IBS and chronic constipation and necrotising enterocolitis in small infants (reviewed in [30]). Apart from this therapeutic approach, it is still difficult to give a general recommendation of probiotics as a preventive measure. The number of prospective, controlled human trials that have been conducted in this field is rather small at present. Limited knowledge within the scientific community and regulatory authorities on suitable markers, as well as regarding the details of how to perform such trials, is the main reason for the lack of appropriate long-term, cost-intensive prevention trials. Recently, a few trials have yielded promising but rather preliminary clinical data or surrogate marker analysis [107-109]. The challenge for the future, based on our growing expertise, is to select adequate measurable parameters, to consider interindividual variations in the composition of the intestinal microbiome and to exclude numerous other putative confounding factors, since regulatory authorities require data from human trials, not just for drugs but also for dietary supplements, to provide scientific support for health claims [1].

\section{Outlook for gut health: a new objective in medicine?}

Medicine in the Western world is undergoing substantial changes. The more advances there are in treatment options, the less affordable they become for everybody. Breaking free of this vicious cycle requires effort not only to manage advanced disease states but also to intervene at an early stage. Only effective strategies in preventive medicine keep our health systems affordable; 
therefore, we must draw more attention to the maintenance of health, and this includes gut health [110-113]. One of the major areas that needs to be addressed is the gut, because epidemiologic and economic data point to the relevance of diseases such as IBS, IBD and CRC, which are, in principle, to a large extent avoidable. So far, great effort has been made to improve CRC prevention strategies, with variable success $[114,115]$. The success rate is limited less by the accuracy of the diagnostic tools and more by dependence on the behaviour of a population and the acceptance of screening programs. Therefore, a major effort in the future must be made to improve acceptance rates of guidelines by physicians and of screenings by the afflicted populations [116]. Moreover, to improve gut health, efforts must not be restricted to malignant diseases such as CRC but must also include inflammatory and so-called functional GI diseases such as IBD and IBS.

Consideration of the overall burden and economic impact of IBS, which afflicts perhaps $10 \%$ of the population in a moderate to severe way, and almost everyone from time to time at lower degrees, makes it clear that every improvement in understanding IBS and care of IBS is a positive step forward for gut health maintenance [117]. There is now overwhelming evidence that the intestinal microbiome is not only changed but also involved in the pathogenesis of IBS and stress-induced GI dysfunction $[118,119]$. Probiotic intervention, however, still needs to be improved [120,121]. We speak about 'good health', and the bacteria that live in our gut are said to be 'in balance' when the number of 'good bacteria' outnumber the number of 'bad bacteria'; however, we need to learn more about the mechanisms underlying such expressions. Moreover, the mechanism of activity for probiotics inside and beyond the gut is also far from clear [122,123]. Overcoming these deficiencies requires a new focus in research and the overcoming of taboos that still exist for gut issues, which are regarded as 'ugly' and 'dirty'. The most relevant first step would be to declare the maintenance of gut health and the improvement of preventive medicine as major goals in future medicine, which would have a positive effect on people's awareness, on research and education and on health insurance coverage.

To focus on new gut health parameters such as microbiome gene analysis, and to combine them with tools such as genomics and metabolomics, might become the basis for a new kind of personalised medicine that nutritionists and dieticians have been seeking for several years [4-6,85]. Indeed, recent genome analysis of the host has revealed that the success of dietetic recommendations probably depends on the genetic makeup of the individual [124]. Similar findings have been described by microbiologists who found that obesity risk and treatment response are associated with the particular composition of the intestinal microbiome [125,126]. Possibly, gut health and general health are dependent not only on the genetics of the host but also on the genetics of the commensal bacteria. The tools required to answer such questions are rapidly advancing and have already allowed adequate analysis in research settings and perhaps also in the near future in health care settings $[1,27]$. The use of such tools in daily practice for diagnostic purposes and for new drug development [127], together with improved communication about gut issues as proposed by several national initiatives in the United Kingdom [128], the Netherlands [129] and Germany (initiative of the Felix-Burda foundation; see http://www.darmgesundheits-check.de/), would likely improve both our understanding of gut health and our approaches to maintaining it. By doing so, an exciting new contribution to preventive, therapeutic and more economically efficient medical practice could be offered.

\section{Summary}

The term 'gut health' has become popular; however, from a scientific point of view, the term is poorly defined and used in different contexts. It covers all aspects, ranging from the Asian understanding of the gut as the middle of spiritual and physical strength to the Western understanding of the GI barrier as a central body site interacting with the environment and involved in the pathophysiology of many intestinal and extraintestinal diseases. The expression 'gut health' lacks clear definition in the scientific literature, although it has been used repeatedly in human medicine and in animal health. Herein a positive definition of 'gut health' is proposed in accordance with the WHO definition of health: 'Gut health is a state of physical and mental well-being in the absence of gastrointestinal complaints that require the consultation of a doctor, in the absence of indications or risks of bowel disease, and in the absence of confirmed bowel disease' (source: Constitution of the World Helath Organization, New York 1946, see http:// www.who.int/governance/eb/who_constitution_en.pdf).

The relevance of gut health is underlined by the fact that its loss is characterised by a large variety of symptoms, often prompting an individual to consult a doctor. Such symptoms are associated with the widespread disease IBS and comprise flatulence, bloating, regurgitation, heartburn, nausea, vomiting, constipation, diarrhoea, food intolerance, incontinence, abdominal pain and cramps, loss of appetite, weight loss and blood in stools. Functional oesophageal and gastric diseases must also be considered in this context. In most cases, such symptoms reflect more or less harmless diseases that might affect quality of life but not mortality. Some of the symptoms, however, such as anorexia, unintended 
weight loss, dysphagia, continuing vomiting, severe abdominal pain or diarrhoea, melena and hematochezia, must be interpreted as alarm signals requiring a detailed examination. This is particularly important if such symptoms occur in individuals with a family history of CRC or in older adults who have never had a colonoscopy.

The mechanisms of ensuring gut health are complex and comprise a healthy lifestyle, a balanced diet, normal GI perfusion, normal GI microbiome and likely a stable mental status. Any major impairment of these mechanisms leads to a breakdown of the GI barrier that defends us against environmental and endogenous hazards. Of particular interest in this context is a better understanding of the interaction between the GI microbiome and the mucosal immune system, which both depend on each other to form an intact GI barrier. Moreover, multiple epithelial functions, apart from nutrient absorption, and functions of the enteric nervous system seem to be of crucial importance to maintaining a functional GI barrier and ultimately gut health. The measurement of gut health is not well established. Two approaches have been recognised: assessment of subjective complaints by using validated questionnaires indicating gut health and assessment of physiological GI function by defining and measuring validated biomarkers related to gut health. Both approaches are equivalent and cannot replace each other.

Gut health can offer a new approach to preventive medicine if we learn more about how to achieve and maintain it. Current medical research is much more focused on the treatment of defined GI diseases rather than on the secondary or even primary prevention of disease. However, preventive medicine is increasingly perceived as being important in medical and economic terms, particularly in the field of gastroenterology. Therefore, scientifically justified approaches to maintaining gut health and to preventing GI diseases are welcome. Although this is an area with many open questions, we have started to learn that lifestyle characteristics, such as balanced diet, moderate but regular exercise and avoidance of chronic stress, but also defined products such as select pre- and probiotics, can support gut health. This topic will concern us even more in the future if we succeed at increasing our knowledge of the underlying mechanisms and how to influence them in a positive way.

\section{Author's information}

SCB has been Professor of Medicine and Chair of Nutritional Medicine and Prevention at the University of Hohenheim, Stuttgart, Germany, since 2004. He is trained as a gastroenterologist and allergologist and used to work in Mainz and Hanover, Germany; Strasburg, France;
Bern, Switzerland; and at Columbia University, New York, NY, USA. In 2005, he became Vice Dean of the Faculty of Life Sciences and member of the managing board of the Life Science Centre, Hohenheim, Germany. Since 2008, he has been an elected officer and board member of the European Society of Parenteral and Enteral Nutrition; since 2009, he has been Medical Director of the Centre of Nutritional Medicine of the Universities of Hohenheim and Tübingen, Germany, and Chair of the Scientific Council of the Max-RubnerInstitute, Karlsruhe, Germany. In 2010, he became President-elect of the German Society of Clinical Nutrition, and he founded the new German Society of Mucosal Immunology and the Microbiome. He is the author of more than 100 scientific papers, author and editor of major textbooks and a member of several editorial boards of scientific journals.

\section{Acknowledgements}

This work resulted from discussions within a scientific committee counselling a German campaign initiated in 2008 to promote gut health and colon cancer prevention, which was kindly supported by the Felix-Burda Foundation, Munich, Germany, and by Yakult Deutschland GmbH, Neuss, Germany. Members of the scientific committee of the campaign are Rudolf Arnold, Munich, Germany; Stephan C Bischoff, Stuttgart, Germany; Maike Groenveld, Bonn, Germany; Petra Mommert-Jauch, Karlsruhe, Germany; Heiner Krammer, Mannheim, Germany; Christa Maar, Munich; and Herbert Lochs, Innsbruck, Austria.

\section{Competing interests}

The author declares that they have no competing interests.

Received: 4 January 2011 Accepted: 14 March 2011

Published: 14 March 2011

\section{References}

1. Cummings $J \mathrm{H}$, Antoine JM, Azpiroz F, Bourdet-Sicard R, Brandtzaeg $P$, Calder PC, Gibson GR, Guarner F, Isolauri E, Pannemans D, Shortt C, Tuijtelaars S, Watzl B: PASSCLAIM: gut health and immunity. Eur J Nutr 2004, 43(Suppl 2):॥118-\|173.

2. Yu F, Takahashi T, Moriya J, Kawaura K, Yamakawa J, Kusaka K, Itoh T, Morimoto S, Yamaguchi N, Kanda T: Traditional Chinese medicine and Kampo: a review from the distant past for the future. J Int Med Res 2006, 34:231-239.

3. Rey E, Talley NJ: Irritable bowel syndrome: novel views on the epidemiology and potential risk factors. Dig Liver Dis 2009, 41:772-780.

4. Tuohy KM, Probert HM, Smejkal CW, Gibson GR: Using probiotics and prebiotics to improve gut health. Drug Discov Today 2003, 8:692-700.

5. Ferguson LR, Shelling AN, Lauren D, Heyes JA, McNabb WC, Nutrigenomics New Zealand: Nutrigenomics and gut health. Mutat Res 2007, 622:1-6.

6. Johnson IT: Gut health, genetics and personalised nutrition. Genes Nutr 2007, 2:53-54.

7. Jacobs DM, Gaudier E, van Duynhoven J, Vaughan EE: Non-digestible food ingredients, colonic microbiota and the impact on gut health and immunity: a role for metabolomics. Curr Drug Metab 2009, 10:41-54.

8. Lallès JP, Bosi P, Smidt H, Stokes CR: Nutritional management of gut health in pigs around weaning. Proc Nutr Soc 2007, 66:260-268.

9. Choct M: Managing gut health through nutrition. Br Poult Sci 2009, 50:9-15.

10. Ereshefsky M: Defining 'health' and 'disease'. Stud Hist Philos Biol Biomed Sci 2009, 40:221-227.

11. Blaut M, Clavel T: Metabolic diversity of the intestinal microbiota: implications for health and disease. J Nutr 2007, 137:751S-755S. 
12. Vrieze A, Holleman F, Zoetendal EG, de Vos WM, Hoekstra JB, Nieuwdorp M: The environment within: how gut microbiota may influence metabolism and body composition. Diabetologia 2010, 53:606-613.

13. Sharma R, Young C, Neu J: Molecular modulation of intestinal epithelial barrier: contribution of microbiota. J Biomed Biotechnol 2010, 2010:305879.

14. Chung $H$, Kasper DL: Microbiota-stimulated immune mechanisms to maintain gut homeostasis. Curr Opin Immunol 2010, 22:455-460.

15. Tsurugizawa $T$, Uematsu A, Nakamura E, Hasumura M, Hirota M, Kondoh T, Uneyama $\mathrm{H}$, Torii K: Mechanisms of neural response to gastrointestinal nutritive stimuli: the gut-brain axis. Gastroenterology 2009, 137:262-273.

16. Neufeld KM, Kang N, Bienenstock J, Foster JA: Reduced anxiety-like behavior and central neurochemical change in germ-free mice. Neurogastroenterol Motil 2011, 23:255-e119.

17. Fasano A, Shea-Donohue T: Mechanisms of disease: the role of intestinal barrier function in the pathogenesis of gastrointestinal autoimmune diseases. Nat Clin Pract Gastroenterol Hepatol 2005, 2:416-422

18. Nieuwenhuis EE, Blumberg RS: The role of the epithelial barrier in inflammatory bowel disease. Adv Exp Med Biol 2006, 579:108-116.

19. Meddings J: The significance of the gut barrier in disease. Gut 2008, 57:438-440.

20. Groschwitz KR, Hogan SP: Intestinal barrier function: molecular regulation and disease pathogenesis. J Allergy Clin Immunol 2009, 124:3-20.

21. Peeters M, Hiele M, Ghoos Y, Huysmans V, Geboes K, Vantrappen G, Rutgeerts $P$ : Test conditions greatly influence permeation of water soluble molecules through the intestinal mucosa: need for standardisation. Gut 1994, 35:1404-1408.

22. Mai $V$, Morris JG Jr: Colonic bacterial flora: changing understandings in the molecular age. J Nutr 2004, 134:459-464.

23. Macfarlane GT, Macfarlane S: Human colonic microbiota: ecology, physiology and metabolic potential of intestinal bacteria. Scand Gastroenterol Suppl 1997, 222:3-9.

24. Bouskra D, Brézillon C, Bérard M, Werts C, Varona R, Boneca IG, Eberl G: Lymphoid tissue genesis induced by commensals through NOD1 regulates intestinal homeostasis. Nature 2008, 456:507-510.

25. Round $J$, Mazmanian SK: The gut microbiota shapes intestinal immune responses during health and disease. Nat Rev Immunol 2009, 9:313-323.

26. Mai $\mathrm{V}$, Draganov PV: Recent advances and remaining gaps in our knowledge of associations between gut microbiota and human health. World J Gastroenterol 2009, 15:81-85.

27. Kinross JM, von Roon AC, Holmes E, Darzi A, Nicholson JK: The human gut microbiome: implications for future health care. Curr Gastroenterol Rep 2008, 10:396-403.

28. Hsiao WW, Metz C, Singh DP, Roth J: The microbes of the intestine: an introduction to their metabolic and signaling capabilities. Endocrinol Metab Clin North Am 2008, 37:857-871.

29. Possemiers S, Grootaert C, Vermeiren J, Gross G, Marzorati M, Verstraete W, Van de Wiele T: The intestinal environment in health and disease: recent insights on the potential of intestinal bacteria to influence human health. Curr Pharm Des 2009, 15:2051-2065.

30. Preidis GA, Versalovic J: Targeting the human microbiome with antibiotics, probiotics, and prebiotics: gastroenterology enters the metagenomics era. Gastroenterology 2009, 136:2015-2031.

31. Jeong $\mathrm{SH}$, Song $\mathrm{YK}$, Cho JH: Risk assessment of ciprofloxacin, flavomycin, olaquindox and colistin sulfate based on microbiological impact on human gut biota. Regul Toxicol Pharmacol 2009, 53:209-216.

32. Tanaka S, Kobayashi T, Songjinda P, Tateyama A, Tsubouchi M, Kiyohara C, Shirakawa T, Sonomoto K, Nakayama J: Influence of antibiotic exposure in the early postnatal period on the development of intestinal microbiota. FEMS Immunol Med Microbiol 2009, 56:80-87

33. Dethlefsen L, Huse S, Sogin ML, Relman DA: The pervasive effects of an antibiotic on the human gut microbiota, as revealed by deep 16S rRNA sequencing. PLOS Biol 2008, 6:e280.

34. Sonnenburg ED, Zheng $H$, Joglekar P, Higginbottom SK, Firbank SJ, Bolam DN, Sonnenburg JL: Specificity of polysaccharide use in intestinal Bacteroides species determines diet-induced microbiota alterations. Cell 2010, 141:1241-1252.

35. Spruss A, Bergheim I: Dietary fructose and intestinal barrier: potential risk factor in the pathogenesis of nonalcoholic fatty liver disease. J Nutr Biochem 2009, 20:657-662.
36. De-Souza DA, Greene LJ: Intestinal permeability and systemic infections in critically ill patients: effect of glutamine. Crit Care Med 2005, 33:1125-1135

37. Gatt M, Reddy BS, MacFie J: Review article: bacterial translocation in the critically ill-evidence and methods of prevention. Aliment Pharmacol Ther 2007, 25:741-757.

38. Iapichino G, Callegari ML, Marzorati S, Cigada M, Corbella D, Ferrari S, Morelli L: Impact of antibiotics on the gut microbiota of critically ill patients. J Med Microbiol 2008, 57:1007-1014.

39. Kinross J, von Roon AC, Penney N, Holmes E, Silk D, Nicholson JK, Darzi A: The gut microbiota as a target for improved surgical outcome and improved patient care. Curr Pharm Des 2009, 15:1537-1545.

40. Welsh FK, Farmery SM, MacLennan K, Sheridan MB, Barclay GR, Guillou PJ, Reynolds JV: Gut barrier function in malnourished patients. Gut 1998, 42:396-401.

41. Collins SM, Bercik P: The relationship between intestinal microbiota and the central nervous system in normal gastrointestinal function and disease. Gastroenterology 2009, 136:2003-2014

42. Rhee $\mathrm{SH}$, Pothoulakis C, Mayer EA: Principles and clinical implications of the brain-gut-enteric microbiota axis. Nat Rev Gastroenterol Hepatol 2009, 6:306-314

43. Hamady M, Knight R: Microbial community profiling for human microbiome projects: tools, techniques, and challenges. Genome Res 2009, 19:1141-1152.

44. Hattori M, Taylor TD: The human intestinal microbiome: a new frontier of human biology. DNA Res 2009, 16:1-12.

45. Beutler B: Inferences, questions and possibilities in Toll-like receptor signalling. Nature 2004, 430:257-263.

46. Cario E: Bacterial interactions with cells of the intestinal mucosa: Toll-like receptors and NOD2. Gut 2005, 54:1182-1193.

47. Strober $W$ : The multifaceted influence of the mucosal microflora on mucosal dendritic cell responses. Immunity 2009, 31:377-388.

48. Krämer S, Sellge G, Lorentz A, Krueger D, Schemann M, Feilhauer K, Gunzer F, Bischoff SC: Selective activation of human intestinal mast cells by Escherichia coli hemolysin. J Immunol 2008, 181:1438-1445.

49. Cerutti $A$, Rescigno M: The biology of intestinal immunoglobulin $A$ responses. Immunity 2008, 28:740-750.

50. Duerkop BA, Vaishnava S, Hooper LV: Immune responses to the microbiota at the intestinal mucosal surface. Immunity 2009, 31:368-376.

51. Wehkamp J, Fellermann K, Herrlinger KR, Bevins CL, Stange EF: Mechanisms of disease: defensins in gastrointestinal diseases. Nat Clin Pract Gastroenterol Hepatol 2005, 2:406-415.

52. Swidsinski A, Sydora BC, Doerffel $Y$, Loening-Baucke $V$, Vaneechoutte $M$, Lupicki M, Scholze J, Lochs H, Dieleman LA: Viscosity gradient within the mucus layer determines the mucosal barrier function and the spatial organization of the intestinal microbiota. Inflamm Bowel Dis 2007, 13:963-970.

53. Guarner F, Bourdet-Sicard R, Brandtzaeg P, Gill HS, McGuirk P, van Eden W, Versalovic J, Weinstock JV, Rook GA: Mechanisms of disease: the hygiene hypothesis revisited. Nat Clin Pract Gastroenterol Hepatol 2006, 3:275-284.

54. Akdis M, Akdis CA: Therapeutic manipulation of immune tolerance in allergic disease. Nat Rev Drug Discov 2009, 8:645-660.

55. Gershon MD, Tack J: The serotonin signaling system: from basic understanding to drug development for functional $\mathrm{Gl}$ disorders. Gastroenterology 2007, 132:397-414.

56. Bischoff SC: Role of mast cells in allergic and non-allergic immune responses: comparison of human and murine data. Nat Rev Immunol 2007, 7:93-104

57. Sudo N, Chida Y, Aiba Y, Sonoda J, Oyama N, Yu XN, Kubo C, Koga Y: Postnatal microbial colonization programs the hypothalamic-pituitaryadrenal system for stress response in mice. J Physiol 2004, 558:263-275.

58. Morgan MY, Blei A, Grüngreiff K, Jalan R, Kircheis G, Marchesini G, Riggio O, Weissenborn K: The treatment of hepatic encephalopathy. Metab Brain Dis 2007, 22:389-405.

59. Ledochowski M, Widner B, Bair H, Probst T, Fuchs D: Fructose- and sorbitol-reduced diet improves mood and gastrointestinal disturbances in fructose malabsorbers. Scand J Gastroenterol 2000, 35:1048-1052.

60. Sandler RH, Finegold SM, Bolte ER, Buchanan CP, Maxwell AP, Väisänen ML, Nelson MN, Wexler HM: Short-term benefit from oral vancomycin treatment of regressive-onset autism. J Child Neurol 2000, 15:429-435. 
61. Bär F, Von Koschitzky H, Roblick U, Bruch HP, Schulze L, Sonnenborn U, Böttner M, Wedel T: Cell-free supernatants of Escherichia coli Nissle 1917 modulate human colonic motility: evidence from an in vitro organ bath study. Neurogastroenterol Motil 2009, 21:559-566.

62. Ait-Belgnaoui A, Eutamene H, Houdeau E, Bueno L, Fioramonti J, Theodorou V: Lactobacillus farciminis treatment attenuates stress-induced overexpression of Fos protein in spinal and supraspinal sites after colorectal distension in rats. Neurogastroenterol Motil 2009, 21:567-573.

63. Azpiroz F, Bouin M, Camilleri M, Mayer EA, Poitras P, Serra J, Spiller RC Mechanisms of hypersensitivity in IBS and functional disorders. Neurogastroenterol Motil 2007, 19(1 Suppl):62-88.

64. Saito YA, Mitra N, Mayer EA: Genetic approaches to functional gastrointestinal disorders. Gastroenterology 2010, 138:1276-1285.

65. Scanlan PD, Shanahan F, Marchesi JR: Human methanogen diversity and incidence in healthy and diseased colonic groups using $\mathrm{mcr} A$ gene analysis. BMC Microbiol 2008, 8:79.

66. Kato K, Sullivan PF, Evengård B, Pedersen NL: A population-based twin study of functional somatic syndromes. Psychol Med 2009, 39:497-505.

67. Dinan TG, Cryan J, Shanahan F, Keeling PW, Quigley EM: IBS: an epigenetic perspective. Nat Rev Gastroenterol Hepatol 2010, 7:465-471.

68. Wei B, Wingender G, Fujiwara D, Chen DY, McPherson M, Brewer S, Borneman J, Kronenberg M, Braun J: Commensal microbiota and CD8 ${ }^{+} \mathrm{T}$ cells shape the formation of invariant NKT cells. J Immunol 2010, 184:1218-1226

69. Lyons A, O'Mahony D, O'Brien F, MacSharry J, Sheil B, Ceddia M Russell WM, Forsythe P, Bienenstock J, Kiely B, Shanahan F, O'Mahony L: Bacterial strain-specific induction of Foxp $3^{+} \mathrm{T}$ regulatory cells is protective in murine allergy models. Clin Exp Allergy 2010, 40:811-819.

70. Guyatt G, Mitchell A, Irvine EJ, Singer J, Williams N, Goodacre R, Tompkins C: A new measure of health status for clinical trials in inflammatory bowel disease. Gastroenterology 1989, 96:804-810.

71. Talley NJ, Phillips SF, Wiltgen CM, Zinsmeister AR, Melton LJ: Assessment of functional gastrointestinal disease: the bowel disease questionnaire. Mayo Clin Proc 1990, 65:1456-1479.

72. Hahn BA, Kirchdoerfer LJ, Fullerton S, Mayer E: Patient-perceived severity of irritable bowel syndrome in relation to symptoms, health resource utilization and quality of life. Aliment Pharmacol Ther 1997, 11:553-559.

73. Barry TL, Kaiser KL, Atwood JR: Reliability, validity, and scoring of the Health Status Questionnaire-12 version 2.0. J Nurs Meas 2007, 15:24-35.

74. Pettit $T$, Livingston $G$, Manela M, Kitchen $G$, Katona C, Bowling A: Validation and normative data of health status measures in older people: the Islington study. Int J Geriatr Psychiatry 2001, 16:1061-1070.

75. Svedlund J, Sjödin I, Dotevall G: GSRS: a clinical rating scale for gastrointestinal symptoms in patients with irritable bowel syndrome and peptic ulcer disease. Dig Dis Sci 1988, 33:129-134.

76. Lewis SJ, Heaton KW: Stool form scale as a useful guide to intestinal transit time. Scand J Gastroenterol 1997, 32:920-924.

77. Francis CY, Morris J, Whorwell PJ: The irritable bowel severity scoring system: a simple method of monitoring irritable bowel syndrome and its progress. Aliment Pharmacol Ther 1997, 11:395-402.

78. Fraser A, Delaney BC, Ford AC, Qume M, Moayyedi P: The Short-Form Leeds Dyspepsia Questionnaire validation study. Aliment Pharmacol Ther 2007, 25:477-486.

79. Adam B, Liebregts T, Saadat-Gilani K, Vinson B, Holtmann G: Validation of the gastrointestinal symptom score for the assessment of symptoms in patients with functional dyspepsia. Aliment Pharmacol Ther 2005, 22:357-363.

80. Drossman DA, Li Z, Toner BB, Diamant NE, Creed FH, Thompson D, Read NW, Babbs C, Barreiro M, Bank L, et al: Functional bowel disorders: a multicenter comparison of health status and development of illness severity index. Dig Dis Sci 1995, 40:986-995.

81. Spiegel B, Bolus R, Harris LA, Lucak S, Naliboff B, Esrailian E, Chey WD, Lembo A, Karsan H, Tillisch K, Talley J, Mayer E, Chang L: Measuring irritable bowel syndrome patient-reported outcomes with an abdominal pain numeric rating scale. Aliment Pharmacol Ther 2009, 30:1159-1170.

82. Labus JS, Mayer EA, Chang L, Bolus R, Naliboff BD: The central role of gastrointestinal-specific anxiety in irritable bowel syndrome: further validation of the Visceral Sensitivity Index. Psychosom Med 2007, 69:89-98.

83. Camilleri M, Northcutt AR, Kong S, Dukes GE, McSorley D, Mangel AW: Efficacy and safety of alosetron in women with irritable bowel syndrome: a randomised, placebo-controlled trial. Lancet 2000, 355:1035-1040.

84. Müller-Lissner S, Koch G, Talley NJ, Drossman D, Rueegge P, DungerBaldaufe C, Lefkowitz M: Subject's global assessment of relief: an appropriate method to assess the impact of treatment on irritable bowel syndrome-related symptoms in clinical trials. J Clin Epidemio/ 2003, 56:310-316.

85. Tuohy KM, Gougoulias C, Shen Q, Walton G, Fava F, Ramnani P: Studying the human gut microbiota in the trans-omics era: focus on metagenomics and metabonomics. Curr Pharm Des 2009, 15:1415-1427.

86. Yazdanbakhsh M, Kremsner PG, van Ree R: Allergy, parasites, and the hygiene hypothesis. Science 2002, 296:490-494.

87. Renz H, Blümer N, Virna S, Sel S, Garn H: The immunological basis of the hygiene hypothesis. Chem Immunol Allergy 2006, 91:30-48.

88. Weinstock JV, Elliott DE: Helminths and the IBD hygiene hypothesis. Inflamm Bowel Dis 2009, 15:128-133.

89. Sauter NS, Schulthess FT, Galasso R, Castellani LW, Maedler K: The antiinflammatory cytokine interleukin-1 receptor antagonist protects from high-fat diet-induced hyperglycemia. Endocrinology 2008, 149:2208-2218.

90. Lê KA, Ith M, Kreis R, Faeh D, Bortolotti M, Tran C, Boesch C, Tappy L: Fructose overconsumption causes dyslipidemia and ectopic lipid deposition in healthy subjects with and without a family history of type 2 diabetes. Am J Clin Nutr 2009, 89:1760-1765

91. World Cancer Research Fund/American Institute for Cancer Research: Food, Nutrition, Physical Activity, and the Prevention of Cancer: A Global Perspective.[http://www.dietandcancerreport.org/].

92. Miller PE, Lesko SM, Muscat JE, Lazarus P, Hartman TJ: Dietary patterns and colorectal adenoma and cancer risk: a review of the epidemiological evidence. Nutr Cancer 2010, 62:413-424

93. Randi G, Edefonti V, Ferraroni M, La Vecchia C, Decarli A: Dietary patterns and the risk of colorectal cancer and adenomas. Nutr Rev 2010, 68:389-408.

94. Chafen JJ, Newberry SJ, Riedl MA, Bravata DM, Maglione M, Suttorp MJ, Sundaram V, Paige NM, Towfigh A, Hulley BJ, Shekelle PG: Diagnosing and managing common food allergies: a systematic review. JAMA 2010, 303:1848-1856.

95. Tack GJ, Verbeek WH, Schreurs MW, Mulder CJ: The spectrum of celiac disease: epidemiology, clinical aspects and treatment. Nat Rev Gastroenterol Hepatol 2010, 7:204-213.

96. Tan S, Tillisch K, Bolus SR, Olivas TI, Spiegel BM, Naliboff B, Chang L, Mayer EA: Traditional Chinese medicine based subgrouping of irritable bowel syndrome patients. Am J Chin Med 2005, 33:365-379.

97. Chopra A: Ayurvedic medicine and arthritis. Rheum Dis Clin North Am 2000, 26:133-144.

98. Cooper K, Squires H, Carroll C, Papaioannou D, Booth A, Logan RF, Maguire C, Hind D, Tappenden P: Chemoprevention of colorectal cancer: systematic review and economic evaluation. Health Technol Assess 2010, $14: 1-206$.

99. Zhang L, Ren X, Alt E, Bai X, Huang S, Xu Z, Lynch PM, Moyer MP, Wen XF, Wu X: Chemoprevention of colorectal cancer by targeting APC-deficient cells for apoptosis. Nature 2010, 464:1058-1061.

100. Heath El, Canto MI, Piantadosi S, Montgomery E, Weinstein WM, Herman JG, Dannenberg AJ, Yang W, Shar AO, Hawk E, Forastiere AA, Chemoprevention for Barrett's Esophagus Trial Research Group: Secondary chemoprevention of Barrett's esophagus with celecoxib: results of a randomized trial. J Natl Cancer Inst 2007, 99:545-557.

101. Swidsinski A, Ladhoff A, Pernthaler A, Swidsinski S, Loening-Baucke V, Ortner M, Weber J, Hoffmann U, Schreiber S, Dietel M, Lochs H: Mucosal flora in inflammatory bowel disease. Gastroenterology 2002, 122:44-54.

102. Kim Y, Kim SH, Whang KY, Kim YJ, Oh S: Inhibition of Escherichia coli 0157:H7 attachment by interactions between lactic acid bacteria and intestinal epithelial cells. J Microbiol Biotechnol 2008, 18:1278-1285.

103. Ukena SN, Singh A, Dringenberg U, Engelhardt R, Seidler U, Hansen W, Bleich A, Bruder D, Franzke A, Rogler G, Suerbaum S, Buer J, Gunzer F, Westendorf AM: Probiotic Escherichia coli Nissle 1917 inhibits leaky gut by enhancing mucosal integrity. PLoS One 2007, 2:e1308.

104. Qin H, Zhang Z, Hang X, Jiang Y: L. plantarum prevents enteroinvasive Escherichia coli-induced tight junction proteins changes in intestinal epithelial cells. BMC Microbiol 2009, 9:63. 
105. Schlee M, Wehkamp J, Altenhoefer A, Oelschlaeger TA, Stange EF, Fellermann $\mathrm{K}$ : Induction of human $\beta$-defensin 2 by the probiotic Escherichia coli Nissle 1917 is mediated through flagellin. Infect Immun 2007, 75:2399-2407.

106. Möndel M, Schroeder BO, Zimmermann K, Huber H, Nuding S, Beisner J, Fellermann K, Stange EF, Wehkamp J: Probiotic E. coli treatment mediates antimicrobial human $\beta$-defensin synthesis and fecal excretion in humans. Mucosal Immunol 2009, 2:166-172.

107. Collado MC, Isolauri E, Salminen S, Sanz Y: The impact of probiotic on gut health. Curr Drug Metab 2009, 10:68-78.

108. Marteau P, Seksik P, Jian R: Probiotics and intestinal health effects: a clinical perspective. Br J Nutr 2002, 88(Suppl 1):S51-S57.

109. De Preter V, Vanhoutte T, Huys G, Swings J, De Vuyst L, Rutgeerts $P$, Verbeke K: Effects of Lactobacillus casei Shirota, Bifidobacterium breve, and oligofructose-enriched inulin on colonic nitrogen-protein metabolism in healthy humans. Am J Physiol Gastrointest Liver Physiol 2007, 292:G358-G368.

110. Beaglehole R, Ebrahim S, Reddy S, Voûte J, Leeder S, Chronic Disease Action Group: Prevention of chronic diseases: a call to action. Lancet 2007, 370:2152-2157.

111. Brownson RC, Fielding JE, Maylahn CM: Evidence-based public health: a fundamental concept for public health practice. Annu Rev Public Health 2009, 30:175-201.

112. Abegunde DO, Mathers CD, Adam T, Ortegon M, Strong K: The burden and costs of chronic diseases in low-income and middle-income countries. Lancet 2007, 370:1929-1938.

113. McGloin A, Delaney L, Hudson E, Wall P: Symposium on 'The challenge of translating nutrition research into public health nutrition'. Session 5: Nutrition communication. The challenge of effective food risk communication. Proc Nutr Soc 2009, 68:135-141.

114. Arber N, Levin B: Chemoprevention of colorectal neoplasia: the potential for personalized medicine. Gastroenterology 2008, 134:1224-1237.

115. Arditi C, Peytremann-Bridevaux I, Burnand B, Eckardt VF, Bytzer $P$, Agréus $L$, Dubois RW, Vader JP, Froehlich F, Pittet V, Schusselé Filliettaz S, Juillerat P, Gonvers JJ, EPAGE II Study Group: Appropriateness of colonoscopy in Europe (EPAGE II): screening for colorectal cancer. Endoscopy 2009, 41:200-208.

116. Prochaska JO: Multiple Health Behavior Research represents the future of preventive medicine. Prev Med 2008, 46:281-285.

117. Spiller R, Aziz Q, Creed F, Emmanuel A, Houghton L, Hungin P, Jones R, Kumar D, Rubin G, Trudgill N, Whorwell P, Clinical Services Committee of the British Society of Gastroenterology: Guidelines on the irritable bowel syndrome: mechanisms and practical management. Gut 2007, 56:1770-1798.

118. Codling C, O'Mahony L, Shanahan F, Quigley EM, Marchesi JR: A Molecular analysis of fecal and mucosal bacterial communities in irritable bowel syndrome. Dig Dis Sci 2010, 55:392-397.

119. Lutgendorff F, Akkermans LM, Söderholm JD: The role of microbiota and probiotics in stress-induced gastro-intestinal damage. Curr Mol Med 2008, 8:282-298.

120. Brenner DM, Moeller MJ, Chey WD, Schoenfeld PS: The utility of probiotics in the treatment of irritable bowel syndrome: a systematic review. Am J Gastroenterol 2009, 104:1033-1049.

121. Hoveyda N, Heneghan C, Mahtani KR, Perera R, Roberts N, Glasziou P: A systematic review and meta-analysis: probiotics in the treatment of irritable bowel syndrome. BMC Gastroenterol 2009, 9:15.

122. Boirivant $M$, Strober $W$ : The mechanism of action of probiotics. Curr Opin Gastroenterol 2007, 23:679-692.

123. Verdu EF: Probiotics effects on gastrointestinal function: beyond the gut? Neurogastroenterol Motil 2009, 21:477-480.

124. Fisher $E$, Boeing $H$, Fritsche A, Doering $F$, Joost HG, Schulze MB: Wholegrain consumption and transcription factor-7-like 2 (TCF7L2) rs7903146: gene-diet interaction in modulating type 2 diabetes risk. Br J Nutr 2009, 101:478-481

125. Turnbaugh PJ, Gordon Jl: The core gut microbiome, energy balance and obesity. J Physiol 2009, 587:4153-4158.

126. Tennyson CA, Friedman G: Microecology, obesity, and probiotics. Curr Opin Endocrinol Diabetes Obes 2008, 15:422-427.

127. Jia W, Li H, Zhao L, Nicholson JK: Gut microbiota: a potential new territory for drug targeting. Nat Rev Drug Discov 2008, 7:123-129.
128. Coussement PA: Communicating about gut health to the consumer: presenting the BENEO Programme. Br J Nutr 2002, 87(Suppl 2):S301-S303.

129. Stolper $E$, van Bokhoven M, Houben $P$, Van Royen $P$, van de Wiel M, van der Weijden T, Jan Dinant G: The diagnostic role of gut feelings in general practice: a focus group study of the concept and its determinants. BMC Fam Pract 2009, 10:17.

130. Muise AM, Walters TD, Glowacka WK, Griffiths AM, Ngan BY, Lan H, Xu W, Silverberg MS, Rotin D: Polymorphisms in E-cadherin $(\mathrm{CDH} 1)$ result in a mis-localised cytoplasmic protein that is associated with Crohn's disease. Gut 2009, 58:1121-1127.

131. Wapenaar MC, Monsuur AJ, van Bodegraven AA, Weersma RK, Bevova MR, Linskens RK, Howdle P, Holmes G, Mulder CJ, Dijkstra G, van Heel DA, Wijmenga C: Associations with tight junction genes PARD3 and MAGI2 in Dutch patients point to a common barrier defect for coeliac disease and ulcerative colitis. Gut 2008, 57:463-467.

132. Mankertz J, Schulzke JD: Altered permeability in inflammatory bowel disease: pathophysiology and clinical implications. Curr Opin Gastroenterol 2007, 23:379-83.

133. Ohman L, Simrén M: Pathogenesis of IBS: role of inflammation, immunity and neuroimmune interactions. Nat Rev Gastroenterol Hepatol 2010, 7:163-173.

134. Thierry AC, Bernasconi E, Mercenier A, Corthésy B: Conditioned polarized Caco- 2 cell monolayers allow to discriminate for the ability of gutderived microorganisms to modulate permeability and antigen-induced basophil degranulation. Clin Exp Allergy 2009, 39:527-536.

135. Arvola T, Moilanen E, Vuento R, Isolauri E: Weaning to hypoallergenic formula improves gut barrier function in breast-fed infants with atopic eczema. J Pediatr Gastroenterol Nutr 2004, 38:92-96.

136. Cani PD, Neyrinck AM, Fava F, Knauf C, Burcelin RG, Tuohy KM, Gibson GR, Delzenne NM: Selective increases of bifidobacteria in gut microflora improve high-fat-diet-induced diabetes in mice through a mechanism associated with endotoxaemia. Diabetologia 2007, 50:2374-2383.

137. Brun P, Castagliuolo I, Di Leo V, Buda A, Pinzani M, Palù G, Martines D: Increased intestinal permeability in obese mice: new evidence in the pathogenesis of nonalcoholic steatohepatitis. Am J Physiol Gastrointest Liver Physiol 2007, 292:G518-G525.

138. Ott SJ, Musfeldt M, Wenderoth DF, Hampe J, Brant O, Fölsch UR, Timmis KN, Schreiber S: Reduction in diversity of the colonic mucosa associated bacterial microflora in patients with active inflammatory bowel disease. Gut 2004, 53:685-693.

139. Swidsinski A, Loening-Baucke V, Herber A: Mucosal flora in Crohn's disease and ulcerative colitis: an overview. J Physiol Pharmacol 2009, 60(Suppl 6):61-71.

140. Schippa S, lebba V, Barbato M, Di Nardo G, Totino V, Checchi MP, Longhi C, Maiella G, Cucchiara S, Conte MP: A distinctive 'microbial signature' in celiac pediatric patients. BMC Microbiol 2010, 10:175.

141. Kassinen A, Krogius-Kurikka L, Mäkivuokko H, Rinttilä T, Paulin L, Corander J, Malinen E, Apajalahti J, Palva A: The fecal microbiota of irritable bowel syndrome patients differs significantly from that of healthy subjects. Gastroenterology 2007, 133:24-33.

142. Tana C, Umesaki Y, Imaoka A, Handa T, Kanazawa M, Fukudo S: Altered profiles of intestinal microbiota and organic acids may be the origin of symptoms in irritable bowel syndrome. Neurogastroenterol Motil 2010, 22:512-519.

143. Thompson-Chagoyan OC, Vieites JM, Maldonado J, Edwards C, Gil A: Changes in faecal microbiota of infants with cow's milk protein allergy: a Spanish prospective case-control 6-month follow-up study. Pediatr Allergy Immunol 2010, 21:e394-e400.

144. Sjögren YM, Jenmalm MC, Böttcher MF, Björkstén B, Sverremark-Ekström E: Altered early infant gut microbiota in children developing allergy up to 5 years of age. Clin Exp Allergy 2009, 39:518-526.

145. Vaahtovuo J, Munukka E, Korkeamäki M, Luukkainen R, Toivanen P: Fecal microbiota in early rheumatoid arthritis. J Rheumatol 2008, 35:1500-1505.

\section{Pre-publication history}

The pre-publication history for this paper can be accessed here: http://www.biomedcentral.com/1741-7015/9/24/prepub

doi:10.1186/1741-7015-9-24

Cite this article as: Bischoff: 'Gut health': a new objective in medicine? BMC Medicine 2011 9:24. 